\title{
LONG TERM EFFECTS OF MINIMUM LEGAL DRINKING AGE LAWS ON ADULT ALCOHOL USE AND DRIVING FATALITIES
}

\author{
Robert Kaestner \\ Benjamin Yarnoff \\ Working Paper 15439 \\ http://www.nber.org/papers/w15439
NATIONAL BUREAU OF ECONOMIC RESEARCH
1050 Massachusetts Avenue
Cambridge, MA 02138
October 2009

The views expressed herein are those of the author(s) and do not necessarily reflect the views of the National Bureau of Economic Research.

NBER working papers are circulated for discussion and comment purposes. They have not been peerreviewed or been subject to the review by the NBER Board of Directors that accompanies official NBER publications.

(C) 2009 by Robert Kaestner and Benjamin Yarnoff. All rights reserved. Short sections of text, not to exceed two paragraphs, may be quoted without explicit permission provided that full credit, including (C) notice, is given to the source. 
Long Term Effects of Minimum Legal Drinking Age Laws on Adult Alcohol Use and Driving Fatalities

Robert Kaestner and Benjamin Yarnoff

NBER Working Paper No. 15439

October 2009

JEL No. I12,I18,K32

\begin{abstract}
$\underline{\text { ABSTRACT }}$
We examine whether adult alcohol consumption and traffic fatalities are associated with the legal drinking environment when a person was between the ages of 18 and 20. We find that moving from an environment in which a person was never allowed to drink legally to one in which a person could always drink legally was associated with a 20 to 30 percent increase in alcohol consumption and a ten percent increase in fatal accidents for adult males. There were no statistically significant or practically important associations between the legal drinking environment when young and adult female alcohol consumption and driving fatalities.
\end{abstract}

Robert Kaestner

Institute of Government and Public Affairs

University of Illinois

815 West Van Buren Street, Suite 525

Chicago, IL 60607

and NBER

kaestner@uic.edu

Benjamin Yarnoff

Department of Economics

University of Illinois at Chicago

601 South Morgan Street

Chicago, IL 60607

byarno2@uic.edu 


\section{Introduction}

Minimum legal drinking age (MLDA) laws are intended to curb alcohol use of young adults and are justified primarily by evidence showing that higher minimum legal drinking ages are associated with reduced alcohol consumption and fewer traffic fatalities among those affected by the law. ${ }^{1}$ Recently, however, there have been calls from presidents of several prominent colleges to lower the minimum drinking age, and to date, 135 presidents of colleges have signed a statement, which is known as the Amethyst Initiative, asking for public officials to:

- Support an informed and dispassionate public debate over the effects of the 21 yearold drinking age.

- Consider whether the $10 \%$ highway fund "incentive" encourages or inhibits that debate.

- Invite new ideas about the best ways to prepare young adults to make responsible decisions about alcohol. ${ }^{2}$

In addition to this high profile questioning of the desirability of a minimum legal drinking age of 21 , several states have recently considered legislative action to lower the legal drinking age. ${ }^{3}$

An important aspect of the renewed debate about the efficacy of a minimum legal drinking age of 21 is whether it has long term benefits. Those who support a legal drinking age of 21 argue that the law reduces alcohol consumption throughout life by reducing adolescent consumption that sets the pattern for lifetime alcohol use. To support this argument, proponents cite research linking early onset of alcohol use to later alcoholism, and research by

\footnotetext{
${ }^{1}$ See, for example, Wagenaar and Toomey (2002) and Fell et al. (2008). Miron and Tetelbaum (2007) present contrary evidence.

${ }^{2}$ See the Amethyst Initiative website: http://www.amethystinitiative.org/; website accessed May 5, 2009.

${ }^{3}$ News reported by United Press International: http:/www.upi.com/Top_News/2008/04/03/Seven-states-considerlower-drinking-ages/UPI-93081207239450/, website accessed May 5, 2009.
} 
neuroscientists on how alcohol affects adolescent brain development. Those who want to lower the legal drinking age argue that early onset of alcohol use is simply a marker for a personality type most prone to alcoholism and not a cause of later alcoholism, and they are skeptical of the neuroscience research because most has been done on rats. They argue that the evidence of long term effects from human subjects is too sparse and inconclusive to justify a minimum drinking age of 21 .

Almost all social science research related to MLDA laws has focused on young adults, and therefore, social science has not contributed much to the debate over the long term consequences of MLDA laws. ${ }^{4}$ In this paper, we begin to fill this gap in the social science research base. We examine whether lower minimum drinking ages during late adolescence are associated with higher rates of alcohol use and traffic fatalities among adults with an average age of 35 . It is widely acknowledged, even by opponents of a legal age of 21 , that a lower minimum drinking ages increase alcohol use among those 18 to 20 , although opponents of an age 21 limit argue (without much evidence) that a lower legal drinking age decreases heavy (e.g., binge) alcohol use. Assuming that lower minimum drinking ages increase alcohol use of those 18 to 20 years of age, adult alcohol consumption would also be higher if alcohol use during late adolescence has long term consequences, as some research suggests. The reduced legal sanctions associated with a lower legal drinking age will increase alcohol use while young, and

\footnotetext{
${ }^{4}$ The only prior study that we are aware of is Cook and Moore (2001). They examined the association between whether a person's state of residence at age 14 had a minimum legal drinking age of 18 (versus higher) and alcohol consumption at approximately age 24 (sample ages were 17 to 31 ). They found that the age 14 drinking environment was significantly associated with binge drinking at later ages; a drinking age of 18 was associated with a 7\% greater probability of binge drinking at least four times in the last month at later ages. One issue of concern about this study is the relevance of the age 14 legal drinking environment, as relatively few 14 year olds drink. In addition, many states lowered the legal drinking age between 1972 and 1976, so a substantial portion (perhaps as many as 25 to 30 percent) of NLSY79 respondents (aged 7 to 18 between 1972 and 1976) faced a legal drinking age at age 18 that was different than at age 14 .
} 
this increase will in turn increase adult use beyond the level that would occur if the drinking age was 21. It is this hypothesis that motivates our research.

We find that lower minimum drinking ages are associated with significantly higher rates of alcohol use and more traffic fatalities among adult males. We do not find similar effects among females. ${ }^{5}$ These findings suggest that a minimum legal drinking age of 21 has benefits that extend beyond adolescence and these benefits need to be considered in the debate over the efficacy of current MLDA laws. Our study also highlights that more social science research is needed in this area and that social science research can contribute significantly to the debate, which is grounded in biology and neuroscience, about the long term consequences of MLDA laws.

\section{Neurobiology, Economics, and Long Term Consequences of MLDA Laws}

Problematic alcohol use is associated with a variety of behavioral characteristics that have been referred to as psychological dysregulation (Clark and Winters 2002; Clark et al. 2008).

"Psychological dysregulation is a deficiency in the ability to regulate attention, emotions and behavior in response to environmental challenges." (p. 376, Clark et al. 2008)

The part of the brain that controls many functions related to psychological dysregulation is the prefrontal cortex. Notably, adolescence is a period during which changes in the prefrontal cortex are at a peak; there is an increase in white matter and a decrease in gray matter in this area of the brain (Klingberg et al. 1999; Spear 2000; Schmithorst et al. 2002; Chambers et al. 2003; White

\footnotetext{
${ }^{5}$ The different effects by gender may be due to different effects of MLDA laws on adolescent alcohol consumption, different neurological and social effects of early alcohol use, or both. There is some evidence that minimum drinking age laws had different effects on male and female adolescents (Kaestner 2000; Cook and Moore 2001). Evidence that neurological effects of adolescent alcohol use differ by gender is also available (Medina et al. 2008). Finally, peer effects on alcohol use have been found to differ by gender (e.g., Duncan et al. 2005).
} 
and Swartzwelder 2004; Nagy et al. 2004; Zhang et al. 2005; Clark et al. 2008). In addition, during adolescence the frontal lobe of the brain increasingly controls behavior, a process known as frontalization (Rubia et al. 2000; White 2004).

White matter is important because it is the tissue through which information is passed to different areas of the brain, for example, for executive cognitive functioning. Executive cognitive functioning, which is the individual's ability to set goals, monitor and regulate behavior, think flexibly and abstractly, and control attention, is a major component of psychological regulation/dysregulation (Luna et al. 2001; Luna and Sweeney 2004; Moss 2008; Clark et al. 2008; McNamee et al. 2008). White matter volume is associated with improved executive cognitive functioning. One study found that performance on tests designed to measure executive cognitive functioning were strongly correlated with white matter volume (Warner et al. 2006). Therefore, changes in white matter in the prefrontal cortex are an important aspect of brain maturation and are likely related to behaviors that depend on psychological regulation such as alcohol use. In fact, white matter development has been shown to be susceptible to disruption by exposure to alcohol. Adolescents who consumed large amounts of alcohol have been found to have smaller prefrontal white matter volume (DeBellis et al. 2005). Similarly, adolescents with high levels of alcohol use have been found to have white matter abnormalities compared with control groups (Tapert and Schweinsburg 2005). These neurological effects of adolescent alcohol use can possibly lead to an impaired ability to achieve psychological regulation and may result in increased rates of alcohol use throughout life.

Adolescence is also a period of change in other parts of the brain than the prefrontal cortex. Changes in the hippocampus and amygdala also occur during this period, and these areas of the brain are thought to affect memory and reward functions (White 2004; Clark et al. 2008). 
Alcohol use has been associated with changes to these areas of the brain (White 2004; Clark et al. 2008). It has been hypothesized that adolescent alcohol use leads to a reduced ability to respond appropriately to risk and reward situations, a problem shown to lead to higher prevalence of risky behaviors such as alcohol consumption (Fromme et al., 1997). Here too, if the neurological effects are permanent, it may result in higher lifetime use of alcohol.

Social factors may also cause early alcohol use to result in a permanent increase in alcohol use. Early use of alcohol may change peer groups, school performance and other behaviors that in turn can cause greater current and future use of alcohol. In addition, early alcohol use can lead to functional and learned tolerance that decreases impairment and may increase future alcohol use (National Institute on Alcohol Abuse and Alcoholism 1995). These social mechanisms reinforce any biological mechanisms that may cause long term effects of minimum drinking age laws on alcohol consumption.

These biological and social effects of alcohol use integrate well with economic models of addiction that have been developed to explain persistent use of alcohol and other addictive substances (e.g., Becker and Murphy 1988). One of the key features of these models is that past consumption influences present consumption. For example, the model of Becker and Murphy (1988) hypothesizes that consumers recognize this inter-temporal link and respond accordingly when making decisions about current consumption. Thus, a (known) future price increase will decrease current consumption because consumers realize that their current consumption will likely raise future consumption at a time when the price will be relatively higher. Neurological changes related to alcohol such as those described above provide a biological basis to link past and current alcohol consumption. 
Adolescence may be a particularly critical period for economic models of alcohol addiction, as they are for neurological models. If alcohol use during adolescence results in contemporaneous and permanent (neurological) decreases in the ability to achieve psychological regulation, then current and future alcohol use are likely to be higher. Individuals (teens) are unlikely to know of these effects, although they may realize that those who consume a lot of alcohol while young tend to also do so while old. However, alcohol use may decrease the ability to recognize the future impact of current consumption because it adversely affects executive cognitive functioning, which itself is still developing during adolescence. Moreover, adolescents have been shown to discount the future more heavily than adults (O'Donoghue and Rabin 2000, Greene 1986, Nurmi 1991).

It is straightforward to apply these considerations to the case of minimum legal drinking age laws. Consider a reduction in the minimum legal drinking age from 21 to 18 . Such a decrease will reduce the full cost of alcohol (inclusive of legal sanctions) for those ages 18 to 20 and as a result will increase their consumption of alcohol. This is shown in Figure 1 by the arrows showing an increase in alcohol consumption prior to age 21.

Figure 1-Long Term Effects of MLDA

Alcohol Consumption

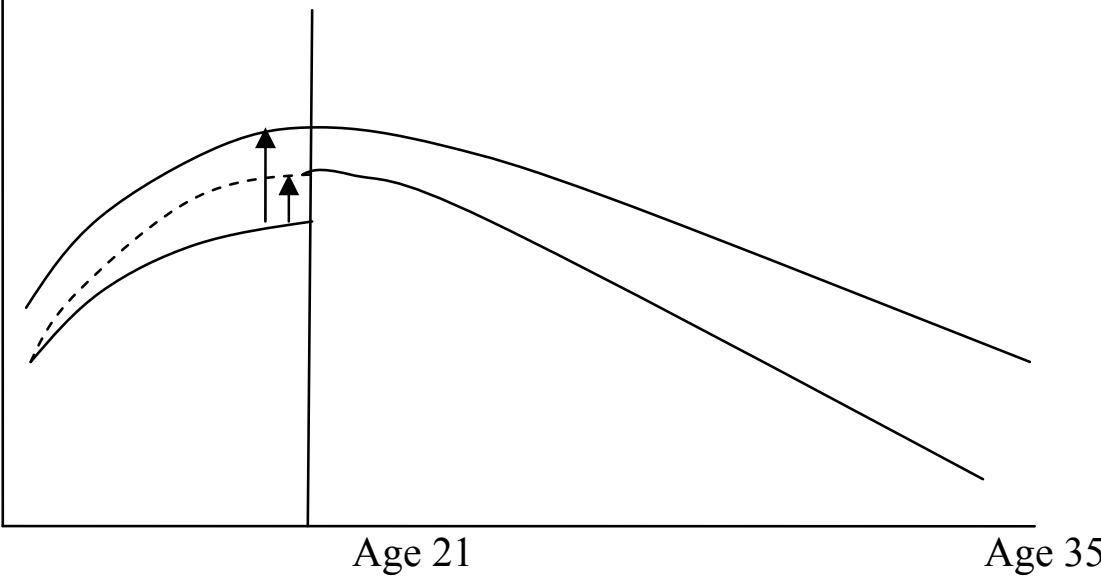


We show two possible patterns. The smaller shift in alcohol consumption prior to age 21 is consistent with a change in consumption due only to reduced legal sanctions. The lower legal drinking age raises consumption prior to age 21 , but at age 21 and beyond when the legal sanctions no longer apply, alcohol consumption is the same as it would be if the legal drinking age was 21 . The larger shift in consumption prior to age 21 reflects the possibility that a lower legal drinking age will have additional effects besides those due to legal sanctions, for example because of the biological and social effects described earlier. In this case, a lower legal drinking age puts the youth on a higher trajectory of alcohol use, and alcohol consumption in later life would be higher for those who could legally drink prior to age 21 . This is the hypothesis that we investigate.

Interestingly, if a lower legal drinking age puts youth on a different trajectory of alcohol consumption, as shown in Figure 1, then estimates of the effect of the MLDA on consumption that use a regression discontinuity design (RDD) based on the age 21 threshold will underestimate the effect of the MLDA — effect of lowering the drinking age, for example, to age 18. In terms of figure 1, the RDD estimate of the effect of the age 21 threshold will correspond to the smaller arrow. Carpenter and Dobkin (2009) conduct such an analysis and find that alcohol consumption, drinking days, increases by 21 percent at the threshold. This is a sizeable effect, and as noted, smaller than the effect of lowering the drinking age if lowering the drinking age changes the trajectory of alcohol use as evidence suggests is possible. It is also important to note that the difference in drinking patterns could grow larger with age, as shown in Figure 1. The biological and social determinants of alcohol use imply that alcohol use is a dynamic (e.g., addictive) behavior, and early differences in use may become exacerbated as people age. 


\section{Research Design}

Our objective is to obtain estimates of the association between the minimum legal drinking age, and adult alcohol use and traffic fatalities that could plausibly be given a causal interpretation. To accomplish this goal, we estimate the following regression model for alcohol consumption:

$$
\begin{aligned}
A L C L_{i j k t} & =\beta_{0}+\delta_{j t}+\gamma_{k}+\beta_{1} P_{R O P_{-}} L E G A L_{j k}+\beta_{2} \text { TREND }_{j k}+\beta_{3} \text { TREND_S }_{j} S \\
& +\beta_{4} A L C_{-} T A X_{j k t}+\beta_{5} \text { DEMOG }_{i j k t}+u_{i j k t}
\end{aligned}
$$

$$
\begin{aligned}
\text { (1) } \mathrm{i}=1, \ldots, \mathrm{N} & \text { (persons) } \\
\mathrm{j}=1, \ldots, 51 & \text { (states) } \\
\mathrm{k}=1960, \ldots, 1975 & \text { (birth year) } \\
\mathrm{t}=1995, \ldots, 2005 & \text { (year) }
\end{aligned}
$$

In equation (1), the dependent variable is alcohol consumption of person $\mathrm{i}$, in year $\mathrm{t}$ who was born in year $\mathrm{k}$ and in state $\mathrm{j}$. The key independent variable is the proportion of years between ages 18 and 20 that the person could legally drink (PROP_LEGAL), which varies by state (j) and year of birth $(\mathrm{k})$. We include controls for state-year fixed effects $\left(\delta_{\mathrm{jt}}\right)$; birth year fixed effects $\left(\gamma_{\mathrm{k}}\right)$; and demographic (DEMOG) characteristics (race and education). ${ }^{6}$

As noted, ideally, we would like to interpret estimates of the association between the minimum legal drinking age and adult alcohol consumption obtained from equation (1) as causal. The primary threat to a causal interpretation of the estimated association is from omitted factors that vary by state and year-of-birth because our key independent variable, the proportion of years between ages 18 and 20 that a person could legally drink, varies only by state and birth year. States changed laws over time and we use these state-specific differences to identify the long term consequences of MLDA laws. To partly address this potential threat, we include in the

\footnotetext{
${ }^{6}$ Gender is not included because all analyses will be done separately by gender.
} 
regression model a state-specific trend for year-of-birth $\left(T R E N D_{j k}\right)$. We allow for a quadratic trend. We also include the average of the sum of federal and state beer taxes $\left(A L C \_T A X_{j k t}\right)$ from the time the person was 18 to the current year. The inclusion of TREND ${ }_{j k}$ and ALC_TAX $X_{j k t}$ is an attempt to control for unmeasured factors that affect alcohol consumption that are state-specific and that vary by birth cohort.

A similar model is estimated for traffic fatalities:

$$
\begin{aligned}
\text { FATAL }_{j k t} & =\alpha_{0}+\pi_{j t}+\rho_{k}+\alpha_{1} \text { PROP_LEGAL }_{j k}+\alpha_{2} \text { TREND }_{j k}+\alpha_{3} \text { TREND_S }_{-} S Q_{j k} \\
& +\alpha_{4} A L C_{-} \text {TAX } \\
j k t & +v_{i j k t}
\end{aligned}
$$

(2)

$$
\begin{array}{ll}
\mathrm{j}=1, \ldots, 51 & \text { (states) } \\
\mathrm{k}=1960, \ldots, 1975 & \text { (birth year) } \\
\mathrm{t}=1995, \ldots, 2005 & \text { (year) }
\end{array}
$$

Equation (2) is similar to equation (1), but is estimated using data aggregated at the state (j), year of birth (k), and year $(\mathrm{t})$ level. The dependent variable is the number of fatal traffic accidents per 100,000 persons in the state/year-of-birth/calendar year cell. Demographic controls are not included in equation (2) because of data limitations. We control for unmeasured state-year and year of birth fixed-effects, and we include a state-specific, year-of-birth (quadratic) trend and average alcohol tax described above.

\section{Data}

The two outcomes we examine are alcohol use and traffic fatalities. Data on alcohol use comes from the Behavioral Risk Factor Surveillance System (BRFSS) from the years 1995 to 2005. We limited the sample to individuals from those survey years born between 1960 and 1975 because these individuals were in their late teens in the early to late 80 s when most states 
raised the MLDA to $21 .^{7}$ Those born in 1960 were 18 years old in 1978 , which is a period when many states had a drinking age of less than 21, age 35 in 1995, and age 45 in 2005 . Those born in 1975 were 18 in 1993, when all states had a minimum drinking age of 21, age 20 in 1995, and age 30 in 2005 . Approximately $36 \%$ of the selected sample could drink legally for some period between ages 18 and 20. In sum, the sample selection criteria provided a group of adults with a mean age of approximately 35 with a significant portion who were able to drink legally between ages 18 and 20.

The BRFSS contains self reported information about alcohol use in the past month. Based on the available information, we constructed several measures of alcohol use: the proportion of days drank alcohol in past month, number of drinks in past month, whether binge drank in past months ( 5 or more drinks at one time), and the proportion of days binge drank in past month. Number of drinks in past month was constructed from information about the number of days drinking in the past month and the average number of drinks on days drinking. Studies evaluating the reliability of self reported measures of substance use in BRFSS have generally found that the data is of high quality (e.g., Nelson et al. 2001).

Additionally, the BRFSS contains information about state of residence, socioeconomic status and demographic characteristics. We used a limited number of personal characteristics in the regression model: age, race, gender, and education status. All variables are measured as dummy variables for each possible category except education, which is grouped into four categories (less than high school degree, high school degree, some college, and bachelor's degree

\footnotetext{
${ }^{7}$ We did not use earlier birth cohorts that were affected by changes in the minimum legal drinking age that occurred in early 70s (mostly 1972-73) because the BRFSS was not a national survey prior to 1995 . Thus, the composition of states would be changing prior to 1995, and therefore, age, period and cohort effects would be mechanically linked to state effects. Including additional birth year cohorts and limiting the data to post 1994 period, as we have done, would make it difficult to identify age, period and cohort effects. These problems are exacerbated by the desire to control for state-specific year of birth trends. Finally, extending the number of birth cohorts provides greater opportunity for the model to be mis-specified given our dependence on the use of state-specific trends in year of birth to control for unobservable variables.
} 
or more). We did not want to control for characteristics that may have been affected by alcohol use such as employment and marital status. We included education, which may also be affected by alcohol use, but show results with and without it in the model. As shown later, including education in the model had virtually no effect on estimates. In addition, results not presented revealed that the minimum legal drinking age was not associated with employment or marital status. State of residence is used to merge state-specific information; most notably information about the minimum legal drinking age when the person was between ages 18 and 20 .

Data on fatal traffic accidents were taken from the Fatality Analysis Reporting System (FARS) from the years 1995 to 2006 . FARS is a dataset containing information about every traffic accident in which there was a fatality including information about driver and passenger characteristics. We aggregated the number of fatal accidents each year by state of residence, year of birth and gender using the characteristics of drivers involved in the accident. Thus, each aggregated cell contains the number of fatal accidents each year that involved drivers of a given age and gender from a particular state. The aggregate number of fatal accidents was then normalized by the relevant (gender and age) population of the state and multiplied by 100,000 to create a measure of the number of fatal accidents per 100,000 residents for a given gender and age. We also aggregated fatal accidents by specific times of the day. We examined two periods: $8 \mathrm{pm}$ to $12 \mathrm{am}$, and 12:01 am to $4 \mathrm{am}$. Focusing on nighttime fatalities is consistent with the literature on the effects of minimum legal drinking ages on youth traffic fatalities. However, the rationale for focusing on this time period is not as strong for adults as it is for youth because among adults, a smaller proportion of fatalities occur at night as compared to youth. At age 40, about 30 percent of all fatalities are between $8 \mathrm{pm}$ to 4 am whereas at age 20 , the similar figure is 45 percent, and the difference is almost all between the 12 am to 4 am period. 
FARS does not provide socioeconomic characteristics and provides only limited demographic attributes - age and gender of driver. Race is either missing or unknown for over half of the drivers. As in the case of BRFSS, state of residence is used to merge information about minimum legal drinking age.

The key independent variable is the minimum legal drinking age. MLDA laws in many states were raised to 21 between 1978 and 1988. We used data from the Distilled Spirits Council of the United States to identify the specific years of law changes in each state. These data have been frequently used in the literature (e.g., Carpenter and Dobkin 2008). Based on state of residence and computed year of birth, we determined if an individual could legally drink at the ages of 18,19 , and 20 and computed the proportion of years between the ages of 18 and 20 that the individual could legally drink. As an alternative measure of a person's drinking status, we classified people into groups by whether they could always legally drink between ages 18 and 20 , sometimes legally drink between these ages, or never legally drink between these ages (reference category). In cases where a law change occurring midyear affected an individual's ability to drink legally, their ability to drink at that age was computed as the proportion of the year for which the lower drinking age was in effect. Laws with grandfather clauses were taken into account when determining the ability to drink legally.

A limitation of both BRFSS and FARS is that there is no information on year of birth. Thus, year of birth was computed as (current year) - (age). There is the potential for measurement error in this computation, so year of birth was alternatively computed as (current year $)-($ age +1$)$. In the case where the two methods produced differing estimates of an individual's ability to drink legally between ages 18 and 20, the observation was dropped; otherwise the first method was used. This exclusion eliminated less than $10 \%$ of the sample. 
A second limitation of both data sets is that there is no information on state of residence at ages 18 to 20 that we can use to construct a measure of the legal drinking environment at that age. Instead, we use the current state of residence to make these assignments. The misclassification of the legal drinking environment resulting from this data limitation is nontrivial. Data from the 2000 US Census suggests that approximately $55 \%$ of persons in our age ranges currently reside in the state that they were born. However, this is likely to be an understatement of the proportion of people who currently reside in the same state they did at age 18. For example, evidence we describe below suggests that using the proportion of people who were born in the same state that they currently reside understates the proportion of persons currently residing in the same state as they were at age 14 by nearly 10 percentage points, which would increase the fraction of the sample correctly assigned to $65 \%$. In addition, approximately $30 \%$ of those people who do not currently reside in the state they were born were born in a bordering state. The correlation between the legal drinking environment at age 18 in a person's current state of residence and in their border states is approximately 0.7 . So we can expect an additional $7 \%$ of the sample to be correctly assigned for this reason. In sum, we expect that at least $70 \%$, but perhaps as much as $80 \%$, of our sample will be assigned the correct legal drinking environment.

To reduce the extent of this measurement problem, in some analyses, we limited the sample to states that had a relatively high proportion of current residents that were born in that state. Using data from the 2000 US Census, we constructed a measure of the proportion of nonimmigrant (non foreign-born) current residents that were born in the same state for three age groups (20 to 30,31 to 40 , and 41 to 50 ). We divided states into two groups: states in which $50 \%$ or less of current residents were born in that state, and states in which more than $50 \%$ of 
current residents were born in that state. We refer to these as high- and low-migration states, respectively. Approximately $56 \%$ of the BRFSS sample and $60 \%$ of the FARS sample lived in what we will refer to as low-migration states. The proportion of current residents born in that state was $66 \%$ and $38 \%$ respectively. ${ }^{8}$ Note that these proportions likely understate substantially the proportion of people who currently reside in the same state they did at age 18 , as described above. It is also the case that low-educated persons are less likely to migrate, and a relatively high proportion of low-educated persons live in the state that they were born. For example, data from the 2000 US Census indicate that for those 31 to 40 the proportion of low-educated persons living in the same state they were born in is 72 percent. Additionally, data from the National Longitudinal Survey of Youth indicate that among those with an average age of 40, approximately 80 percent of those with a high school degree or less live in the same state as they did at age 14. Given this evidence, we limit the sample to low-educated, which is defined as high school or less, to reduce measurement error associated with assigning the legal drinking environment based on current state of residence.

The purpose of limiting the sample to those in low-migration states, or to low-educated persons, is to reduce measurement error. If such measurement error was random, we would expect larger (absolute value) estimates because random measurement error biases estimates toward zero. ${ }^{9}$ However, the association between the legal drinking age and alcohol consumption (fatalities) may be heterogeneous and may differ by state groupings (i.e., low-migration states) and by education status. Therefore, it is not clear that estimates obtained using these samples

\footnotetext{
${ }^{8}$ In addition, the lack of information about state of residence at ages 18 to 20 also led us to drop persons identified as Hispanic from the alcohol use analysis because of their greater likelihood of not living in that state between ages 18 and 20. We are unable to exclude Hispanics in the analysis of traffic fatalities because information about race/ethnicity is frequently either missing or unknown.

9 This is not necessarily the case when the mis-measured variable is binary. In the binary case, the error and true variable are negatively correlated (Aigner 1973; Savoka 2000). However, unless more than half of the sample is mis-classified, estimates will still be biased toward zero.
} 
will be larger in absolute value. Nevertheless, the estimates from analyses using these subgroups will be much less affected by measurement error. Thus, while such estimates may not be informative about the long term effect of the MLDA for the entire sample, they are unlikely to be seriously biased by measurement error.

\section{Results}

Table 1 presents estimates of the association between legal drinking restrictions when young and the proportion of days that adults drank alcohol in the past month. The format of the table is as follows. Estimates for males are presented in the top half of the table and those for females are in the bottom half. For each sample (male and female), several different model specifications are estimated. Estimates in column (1) are from a model that includes state-year fixed effects, year-of-birth fixed effects, and race fixed effects. Estimates in column (2) are from a model that includes the previous controls and a quadratic, state-specific trend for year-of-birth. In column (3), educational attainment (HS, some college, BA or more) is added to the model. Estimates in columns (4) and (5) are from a model that is identical to that in column (3), but the samples are limited to those in low-migration states (column 4) or low-educated persons (column 5). Finally, we also estimate each model (as indicated by column) twice using a different measure of the legal drinking environment: either the proportion of years between ages 18 and 20 that a person was able to legally drink, or two dummy variables indicating that a person could always drink legally between ages 18 and 20 or that a person could drink legally only some of the years between ages 18 and 20 (reference group is never able to legally drink).

Estimates in Table 1 suggest that the legal drinking environment while young has no statistically, or practically important, association with the proportion of days in the past month 
that adults drank alcohol. There are no statistically significant estimates and all estimates are small in magnitude. The largest estimate is in column (5) for males and it indicates that always being able to drink while young is associated with a 10 percent, or 0.017 percentage point, increase in the proportion of days that adult males drank. All other estimates are considerably smaller and there is no consistent pattern to the estimates to suggest an association between the legal drinking environment while young and the proportion of days that adults drank.

The next outcome we investigated was the number of drinks consumed in the past month. Estimates related to this outcome are presented in Table 2. Estimates in the top half of the table indicate that among adult males, there is a significant association between the legal drinking environment while young and the number of drinks consumed in the past month. Estimates in columns (1) through (4) indicate that moving from an environment of never being able to drink to always being able to drink is associated with an increase in consumption of approximately 3.5 drinks (18 percent) per month.

It is noteworthy that estimates in columns (1) through (3) are so similar. Adding controls for state-specific, year-of-birth trends and the average state alcohol tax for each birth cohort had little effect on estimates. Similarly, adding education to the model, a factor that may be influenced by alcohol use, had little effect on estimates.

Limiting the sample to those from low-migration states yields estimates that are also similar to those obtained using the complete sample. While we expected that limiting the sample in this way would reduce measurement error and likely increase in absolute value the magnitude of estimates, we did not find this to be the case. However, as noted, it is not necessarily true that we should find larger estimates in this sample, because although measurement error may be less, there may be differences in the underlying association. We stress, however, that the estimate in 
column (4) is much less likely to be affected by measurement error. Approximately $70 \%$ of persons in these states were born in that state and it is likely that a larger proportion (perhaps $80 \%$ ) of persons lived in that state at age 18 . While estimates in column (4) may not be useful for making inferences about the effect of the young adult legal drinking environment on adult alcohol consumption in all states, it is an arguably credible estimate of the effect in those states. Finally, standard errors of estimates are relatively large and it is not possible to differentiate in a statistical sense between estimates in columns (3) and (4).

Estimates pertaining to the sample of low-educated persons (column 5) indicate that always being able to drink legally between the ages of 18 and 20 is associated with an increase in alcohol consumption of between 5.9 (27 percent) and 7.7 (36 percent) drinks per month for this group. In this case, estimates are larger than those obtained for the complete sample. This may reflect less measurement error or a different underlying relationship between minimum legal drinking age and alcohol consumption. Here again, however, we stress that for this group, measurement error is not severe - according to data from the NLSY, approximately $80 \%$ of loweducated persons live in the same state of residence as they did at age 14 . Thus, it is likely that an even higher proportion of this group lived in the same state of residence as they did at age 18, and the estimate for this group is likely to be credible even if it may not be useful for making inferences about the effect of the young adult legal drinking environment on adult alcohol consumption for all persons.

In contrast to males, estimates related to females indicate that there is no statistically significant association between the legal drinking environment while young and the number of drinks consumed in the past month. Besides the lack of statistical significance, most estimates for the female sample are relatively small and not robust to small changes in specification. 
Consider estimates in column (3). The estimate associated with the dummy variable "Always Legal" is 0.188 . However, changing the specification of the legal drinking environment only slightly, using the proportion of years that a person can legally drink instead of the two dummy variables ("Sometimes" and "Always"), yields an estimate of the same association of -0.549 . Neither estimate is particularly large. Only among the low-educated sample of women do we obtain an estimate that is not small, but this estimate is not statistically significant and not consistent with other estimates.

Table 3 presents estimates of the association between legal drinking restrictions when young and the probability that an adult had five or more drinks at one time (binge drinking) in the past month. In general, estimates suggest that there is not a statistically significant, or practically important, association between the legal drinking environment while young and the probability of binge drinking in past month. The exception is for the low-educated male sample. Among such males, always being able to drink legally between ages 18 and 20 is associated with a 4.9 to 5.8 percentage point, or 16 to 19 percent, increase in the probability of binge drinking. These estimates are consistent with the pattern of results for the complete sample of males; estimates in columns (1) through (4) are similar and suggest that being legally able to drink in late adolescence is associated with a five percent increase in adult male binge drinking.

We also examined whether the proportion of days of binge drinking episodes in the past month among adults was associated with the legal drinking environment while young. Table 4 presents these estimates. Here, we find evidence of a statistically significant association for males, but not females. Among adult males, the estimate in column (3) indicates that those who grew up in an environment in which they were always able to drink legally between the ages of 18 and 20 have a 1.2 percentage point ( 30 percent) higher proportion of binge drinking days in 
the past month than those who grew up in an environment in which they were never allowed to legally drink. Again, estimates in columns (1) through (4) are quite similar. For low-educated males, always being legally able to drink versus never being able to legally drink is associated with a 2.6 percentage point $(50 \%)$ increase in the proportion of binge drinking days. We note that analyses underlying Table 4 have limited statistical power to detect small effects. In addition, while point estimates are large, standard errors do not rule out much smaller (or larger) effects. Finally, we reiterate that estimates obtained using the low-migration and low-educated samples are much less likely to be affected by measurement error.

To summarize, estimates presented to this point indicate that the legal drinking environment when young appears to have lasting effects for males. Men who grew up in an environment that allowed them to drink between the ages of 18 and 20 reported drinking a greater number of drinks in the past month and more episodes of binge drinking in the past month than men who grew up in an environment that prohibited them from drinking during late adolescence. Magnitudes of the associations were non-trivial suggesting differences of 20 to 30 percent in these measures of alcohol use, and even larger for low-educated males. No such associations were found for females.

One question that arises is whether effect sizes of this size are plausible. We believe so for two reasons. First, our estimates are in line those in Cook and Moore (2001), which is the only other study of this type. Cook and Moore (2001) reported that a MLDA of 18 (versus higher), measured when a person was 14, was associated with a 7 percent increase in severe (at least four times) binge drinking at approximately age 24 . However, this was for a sample of both men and women, but as Cook and Moore (2001) also showed, the effect of the MLDA on binge drinking of those ages 18 to 21 who were constrained by the law was nearly three times larger 
for males than females. Extrapolating from this estimate of the male-female difference suggests a 21 percent effect of the age 14 drinking environment on binge drinking at age 24 . This is similar in magnitude to what we found. Second, as noted above, there are plausible reasons to expect that the effect of minimum legal drinking age laws will grow with age because of the neurological and social aspects of alcohol addiction. Cook and Moore (2001) reported a contemporaneous effect of the MLDA of approximately 20 percent for males. Similarly, Carpenter and Dobkin (2009) reported that a MLDA of 21 reduced drinking of 20 year olds by 21 percent, which is an underestimate of the effect of lowering the MLDA.. Therefore, our finding of a 20 to 30 percent effect of the legal drinking environment while young on alcohol use of adult males at age 35 is quite plausible.

To investigate whether the legal drinking environment had any association with other outcomes related to alcohol use, we conducted similar analyses for two measures of health, the proportion of days in poor mental and poor physical health, and a measure of tobacco usewhether a person smoked at all in the past month. ${ }^{10}$ These estimates are presented in Table 5. Only those estimates obtained from a model corresponding to column (3) in the tables presented earlier are shown. In general, estimates in Table 5 are statistically insignificant and small in magnitude when measured against the mean. The only exception is for females and the estimate of the association between the proportion of years between ages 18 and 20 that a person could legally drink and the proportion of days in poor mental health. However, when we use a slightly different characterization of the legal drinking environment when young (i.e., always or sometimes legal), this significant association is no longer evident. In sum, there is little evidence

\footnotetext{
${ }^{10}$ We also examined current marital status and employment. Results indicated that there was no statistically significant or practically important association between minimum legal drinking age and current marital status and employment.
} 
of an association between the legal drinking environment while young and the outcomes shown in Table 5.

Given that we have found evidence consistent with a long lasting effect of the legal drinking environment while young on alcohol use of adult males, we investigated whether this apparent change in alcohol consumption was also associated with traffic fatalities. Unlike selfreported alcohol use, traffic fatalities are an objective measure of greater alcohol use because of the strong, firmly established association between alcohol use and traffic fatalities. Moreover, for males, we found evidence of an association between the legal drinking environment while young and heavy alcohol use - those legally allowed to drink while young reported a greater number of drinks in the past month and a higher proportion of days binge drinking. It is likely that this elevated use of alcohol, which we found to be non-trivial in magnitude, would result in more traffic fatalities.

Table 6 presents estimates of the association between the legal drinking environment while young and fatal traffic accidents among adults. We consider two measures of fatal accidents — all accidents and evening ( $8 \mathrm{pm}$ to $12 \mathrm{am}$ ) accidents. Estimates are obtained from model specifications similar to those used for alcohol. There are only a few differences. We do not have information about education and race/ethnicity, so we cannot control for these variables. Estimates pertaining to all fatal accidents are presented in the top half for both males and females, and estimates pertaining to evening fatal accidents are presented in the bottom half.

We focus the discussion on estimates in columns (2) and (3) because, unlike the case of alcohol consumption, there is evidence that inclusion of controls for state-specific trends for year-of-birth matter. ${ }^{11}$ Estimates in these columns are obtained from arguably a more credible

\footnotetext{
${ }^{11}$ Some (as a previous reader of the paper did) may ask why the inclusion of state-specific trends matter for traffic fatalities and not alcohol consumption. The answer is that there is no reason for the (mediating) effect of this control
} 
specification. For males, estimates indicate that growing up in an environment that allowed drinking between ages 18 and 20, versus not being able to drink legally during these years, is associated with an increase in fatal traffic accidents as an adult. In the top panel, estimates in column (2) indicate that traffic fatalities (per 100,000) of those who were always able to legally drink between ages 18 and 20 are between 2.6 (9 percent) and 3.1 (11 percent) higher than for those who were never able to legally drink between ages 18 and 20. A similar result is obtained in the case of evening accidents; those always able to legally drink had approximately 10 percent more accidents than those never able to legally drink. Restricting the sample to low-migration states (column 3) yields similar estimates, although slightly larger in magnitude. In other results (not presented), we obtained estimates of the association between the legal drinking environment while young and fatal accidents between $12 \mathrm{am}$ and $4 \mathrm{am}$. Estimates from these regressions indicated that the legal drinking environment was not associated with fatal accidents during this period of the day. ${ }^{12}$

Among females, estimates in the top half of Table 6 indicate that there is no statistically significant, or practically important, association between the legal drinking environment while young and fatal accidents of adults. However, there is an association between the legal drinking environment and evening fatal accidents for females. This is surprising given the absence of any evidence that the legal drinking environment while young was associated with increased alcohol consumption for females. Some caution should be used in interpreting the estimates for females in the context of evening accidents because of the lack of statistical power; standard errors of the

variable to be symmetric in its importance. There is simply more changes in traffic fatalities that are correlated with year of birth and differ by state than in alcohol consumption.

${ }^{12}$ It is important to note that the time of day pattern of traffic accidents is very different for adults than youth. Most studies of the effect of alcohol and alcohol policies on youth traffic accidents focus on the night ( 8 p.m. to 12 a.m.) and late night (12 a.m. to 4 a.m.) period. This is because these periods of the day constitute a relatively large share of all traffic accidents for youth. This is not the case for adults. The late night period has a much smaller proportion of traffic fatalities among adults than youths. 
estimates are large and unable to detect effect sizes below approximately 30 percent. More importantly, these estimates are inconsistent with estimates of the association between legal drinking environment and all fatal accidents for females. Finally, in the case of nighttime (12 am to 4am) fatal accidents (results not presented), estimates of the association between the legal dinking environment while young and adult accidents indicated no significant associations.

\section{Conclusion}

There is a large literature on the effects of minimum legal drinking age laws on young adult's use of alcohol and traffic fatalities. The preponderance of evidence from this literature suggests that higher minimum legal drinking ages reduces alcohol consumption and traffic fatalities among young adults, and this evidence has been used to justify a minimum drinking age

of 21. Recently, however, there has been a renewed debate over the wisdom of having a minimum legal drinking age of 21 . Opponents of the minimum drinking age of 21, most notably university administrators associated with the Amethyst Initiative, argue that legal sanctions have not prevented drinking by those age 18 to 20 and, in fact, have exacerbated problem drinking (e.g., binge drinking). Empirical evidence to support this view has been provided by Miron and Tetelbaum (2007).

An issue that is relevant to the debate over the efficacy of a minimum drinking age of 21 , but that has largely been ignored by the social science research community, is whether a minimum drinking age of 21 has long term consequences. Supporters of the higher legal drinking age often argue that a higher legal drinking age has long term benefits, but support for this argument is sparse and at best preliminary. Most of the evidence comes from neurobiology 
and studies of brain imaging and laboratory experiments with rats. Scientists involved in these studies readily admit the preliminary nature of the research:

"Several small cross-sectional studies have suggested that there may be measurable differences between adolescents with AUD [alcohol use disorders] and reference adolescents in specific areas of brain structure and function. ... Policies advocating alcohol abstinence during adolescence would be supported by findings indicating augmented adverse effects on brain development. In this context, it is not surprising that the available findings have sometimes been over-interpreted. While the assertion that the adolescent brain is invulnerable to alcohol effects is implausible, research on the effects of alcohol on adolescent brain has not, as of yet, produced definitive results." (p. 381, Clark et al. 2008)

The absence of social science research on the long term consequences of minimum legal drinking age laws is notable and unnecessary. Social scientists have the ability to provide empirical evidence as to whether higher minimum drinking ages have lasting effects. While neuroscience can provide the biological basis of these effects, eventually it is necessary to assess whether long term effects exist.

In this paper, we presented the results of an analysis of the long term consequences of higher minimum legal drinking ages. We examined whether differences in the legal drinking environment between ages 18 and 20 is associated with alcohol use and fatal traffic accidents among adults with an average age of 35 . We found that moving from an environment in which a young male was never allowed to drink legally to one in which a young male could always drink legally was associated with a 20 to 30 percent increase in alcohol consumption of adult males, and a ten percent increase in fatal traffic accidents for adult males. These estimates are in line 
with the only other study of this type (Cook and Moore 2001) and with the nature of alcohol addiction, which suggests progressively larger effects with age.

These estimates, if true, imply substantial benefits of a minimum drinking age of 21 . To provide a very rough estimate of one benefit, we assume that reducing the minimum legal drinking age to 18 from 21 will (in the long run) increase fatal traffic accidents by ten percent (Table 6 estimate for those with average age of 35) for all males between the ages of 21 to 80 . Data from FARS for the year 2007 on the number of fatal accidents involving male drivers between the ages 21 and 80 , suggests that a minimum drinking age of 21 will prevent 3,480 fatal accidents and will save 3,956 lives per year. ${ }^{13}$ The value of these lives can be computed using estimates of the value of life remaining for men of different ages. Murphy and Topel (2006) provide such estimates and they are listed in the table below next to the number of lives saved. ${ }^{14}$ Assuming that all those who die in an accident are in the same age range as the driver, the total value of the lives saved in a year from a higher minimum drinking age is more than $\$ 20$ billion.

Table 7: Value of Lives Saved from a Minimum Drinking Age of 21

\begin{tabular}{|l|c|c|c|c|c|c|}
\hline $\begin{array}{l}\text { Age of } \\
\text { Driver }\end{array}$ & $\begin{array}{c}\text { Number } \\
\text { of } \\
\text { Accidents }\end{array}$ & $\begin{array}{c}\text { Fatalities } \\
\text { per } \\
\text { Accident }\end{array}$ & $\begin{array}{c}\text { Number of } \\
\text { Fatalities }\end{array}$ & $\begin{array}{c}\text { Lives Saved } \\
\text { (Assume 10\% } \\
\text { of Accidents) }\end{array}$ & $\begin{array}{c}\text { Value of } \\
\text { Remaining } \\
\text { Life } \\
\text { (millions \$) }\end{array}$ & $\begin{array}{c}\text { Value of } \\
\text { Lives Saved } \\
\text { (millions \$) }\end{array}$ \\
\hline $21-30$ & 10081 & 1.15 & 11621 & 1162 & 7 & 8135 \\
\hline $31-40$ & 7193 & 1.12 & 8092 & 809 & 6 & 4855 \\
\hline $41-50$ & 7297 & 1.13 & 8272 & 827 & 5 & 4136 \\
\hline $51-60$ & 5607 & 1.14 & 6383 & 638 & 3.5 & 2234 \\
\hline $61-70$ & 2873 & 1.13 & 3246 & 325 & 2 & 649 \\
\hline $71-80$ & 1753 & 1.11 & 1943 & 194 & 1.5 & 291 \\
\hline & & & & & & \\
\hline Total & 34804 & & 39557 & 3956 & & 20301 \\
\hline
\end{tabular}

\footnotetext{
${ }^{13}$ The FARS data can be accessed at: http://www-fars.nhtsa.dot.gov/QueryTool/QuerySection/SelectYear.aspx, website accessed May 5, 2009.

${ }^{14}$ We used approximate values based on Figure 3 in Murphy and Topel (2006).
} 
The $\$ 20$ billion represents just part of the benefits of a minimum legal drinking age of 21, as there may be other benefits from lower alcohol use besides fewer traffic fatalities. Of course, there are also costs associated with a minimum legal drinking age of 21 , which may be substantial. At a minimum, the cost of the higher drinking age is the value of foregone alcohol consumption of young adults and any other intangible costs such as the erosion of the respect for the law that comes with frequent violation of the law. A more complete assessment of these costs and benefits would be valuable. Here we have provided an estimate of just one benefit, albeit one with great public policy importance.

To summarize, we found that a minimum legal drinking age of 21 , versus a minimum age of 18 , is associated with a 20 to 30 percent reduction in adult male alcohol use and a ten percent reduction in fatal traffic accidents with adult male drivers. These estimates support arguments made by those in favor of keeping the minimum legal drinking age at 21 that such laws have long term, beneficial consequences. Importantly, the evidence we present is a direct assessment of that argument and does not rely on hypotheses of long term effects of such laws derived from neurobiological studies of how alcohol use affects adolescent brain development. Clearly, more research in this area by social scientists is needed. While neurobiology can provide a biological basis for long term effects of minimum drinking age laws, such effects eventually have to be measured to assess whether they exist. We have provided such an assessment. 


\section{References}

Dennis Aigner. "'Regression With a Binary Independent Variable Subject to Errors of

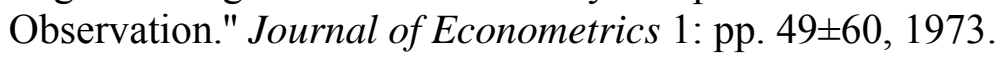

Becker, G., Murphy, K. 1988. “A Theory of Rational Addiction.” The Journal of Political Economy. 96(4): 675-700.

Chambers, R., Taylor, J., Potenza, M. 2003. "Developmental Neurocircuitry of Motivation in Adolescence: A Critical Period of Addiction Vulnerability." American Journal of Psychiatry. 160:1041-1052.

Clark, D., Thatcher, D., and Tapert, S. 2008. “Alcohol, Psychological Dysregulation, and Adolescent Brain Development." Alcoholism: Clinical and Experimental Research. 32(3): 375-385.

Clark, D. and Winters, K., 2002. "Measuring Risks and Outcomes in Substance use Disorders Prevention Research.” Journal of Consulting and Clinical Psychology. 70: 1207-1223.

Cook, Phillip and Moore, Michael. 2001. "Environment and Persistence in Youthful Drinking Patterns." In Risky Behavior among Youths: An Economic Analysis, Editor Jonathan Gruber. University of Chicago Press, p.375-438.

DeBellis, M., Narasimhan, A., Thatcher, D., Keshavan, M., Soloff, P., Clark, D. 2005. "Prefrontal Cortex, Thalamus and Cerebellar Volumes in Adolesent Onset Alcohol Use Disorders." Alcoholism: Clinical and Experimental Research. 29:1590-1600.

Duncan, G., Boisjoly, J., Kremer, M., Levy, D., and Eccles, J. 2005. "Peer Effects in Drug Use and Sex Among College Students." Journal of Abnormal Psychology. 33(3): 375-385.

Environmental Protection Agency. 2003. Technical addendum: methodologies for the benefits analysis of the Clear Skies Act of 2003. September. Washington, DC: EPA.

Fell, J., Fisher, D., Voas, R., Blackman, K., and Tippetts, A. 2008. "The relationship of underage drinking laws to reductions in drinking drivers in fatal crashes in the United States." Accident Analysis and Prevention. 40(4): 1430-1440.

Fromme, K., Katz, E., Rivet, K. 1997. “Outcome Expectancies and Risk-Taking Behavior.” Cognitive Therapy and Research. 21:421-442.

Greene, A. 1986. "Future-Time Perspective in Adolescence: The Present of Things Future revisited. Journal of Youth and Adolescence. 15: 99-113.

Kaestner, Robert. 2000. "A Note on the Effect of Minimum Drinking Age Laws on Youth Alcohol Consumption." Contemporary Economic Policy 18(3):315-325. 
Klingberg, T., Vaidya, C., Gabrieli, J., Moseley, M., Hedehus, M. 1999. "Myelination and Organization of the Frontal White Matter in Children: A Diffusion Tensor MRI Study." Neuroreport. 10:2817-2821.

Luna, B., Sweeney, J. 2004. "The Emergence of Collaboration Brain Function: MRI Studies of the Development of Response Inhibition.” Annual NY Academy of Science. 1021:296309.

Luna, B., Thulborn, K., Munoz, D., Merriam, E., Garver, K., Minshew, N., Keshavan, M., Genovese, C., Eddy, W., Sweeney, J. 2001. "Maturation of Widely Distributed Brain Function Subserves Cognitive Development.” Neuroimage. 13:786-793.

McNamee, R., Dunfee, K., Luna, B., Clark, D., Eddy, W., and Tarter, R. 2008. "Brain Activation, Response Inhibition, and Increased Risk for Substance Use Disorder." Alcoholism: Clinical and Experimental Research. 32(3): 405-413.

Medina, K., McQueeny, T., Nagel, B., Hanson, K., Schweinsburg, A., and Tapert, S. 2008. "Prefrontal Cortex Volumes in Adolescents With Alcohol Use Disorders: Unique Gender Effects." Alcoholism: Clinical and Experimental Research. 32(3): 386-394.

Miron, J. and Tetelbaum, E. 2007. "Does the Minimum Legal Drinking Age Save Lives?" NBER Working Paper \#w1325.

Moss, H. 2008. "Special Section: Alcohol and Adolescent Brain Development." Alcoholism: Clinical and Experimental Research. 32(3): 427-429.

Murphy, K. and Topel, R. 2006. The Value of Health and Longevity." Journal of Political Economy. 114(5): 871-904.

Nagy, Z., Westerberg, H., Klingberg, T. 2004. "Maturation of White Matter is Associated with the Development of Cognitive Functions During Childhood.” Journal of Cognitive Neuroscience. 16:1227-1233.

National Institute on Alcohol Abuse and Alcoholism. 2005. "Alcohol Alert." National Institute on Alcohol Abuse and Alcoholism Alert No. 28 PH 356.

Nelson DE, Holtzman D, Bolen J, Stanwyck CA, Mack KA. 2001 "Reliability and Validity of Measures from the Behavioral Risk Factor Surveillance System (BRFSS).” Social and Preventive Medicine. 46(Supplement):S03-S42.

Nurmi, J. 1991. "How Do Adolescents See Their Future? A Review of the Development of Future Orientation and Planning." Developmental Review. 11: 1-59.

O’Donoghue, Ted and Rabin, Matthew. 2000. "Risky Behavior Among Youths: Some Issues from Behavioral Economics." In Jon Gruber, editor, Youthful Risky Behavior: An Economic Perspective. University of Chicago Press and NBER, Chicago, IL: 29-68. 
Rubia, K., Overmeyer, S., Taylor, E., Brammer, M., Williams, S., Simmons, A., Andrew, C., and Bullmore, E. 2000. "Functional frontalisation with age: mapping neurodevelopmental trajectories with fMRI." Neuroscience and Biobehavioral Reviews. 24(1): 13-19.

Savoka, Elizabeth. 2000. "Measurement Errors in Binary Regressors: An Application to Measuring the Effects of Specific Psychiatric Diseases on Earnings." Health Services and Outcomes Research Methodology 1:149-164.

Schmithorst, V., Wilke, M., Dardzinski, B., Hollard, S. 2002. "Correlation of White Matter Diffusivity and Anisotropy with Age During Childhood and Adolescence: A CrossSectional Diffusion Tensor MRI Study.” Radiology. 222:212-218.

Spear, L. 2000. "The Adolescent Brain and Age-Related Behavioral Manifestations." Neuroscience and Biobehavior Reviews. 24:417-463.

Tapert, S., Schweinsburg, A. 2005. "The Human Adolescent Brain and Alcohol Use Disorders," in Recent Developments in Alcoholism, XVII, Research on Alcohol Problems in Adolescents and Young Adults (Galanter M ed), pp 349-364. Kluwer Academic, Norwell,MA.

Wagenaar, A. and Toomey, T. 2002. "Effects of minimum drinking age laws: review and analyses of the literature from 1960 to 2000." Journal of Studies on Alcohol. Supplement 14: 206-225.

Warner, T., Behnke, M., Eyler, F., Padgett, K., Leonard, C., Hou, W., Garvan, C., Schmalfuss, I., Blackband, S. 2006. "Diffusion Tensor Imaging of Frontal White Matter and Executive Functioning in Cocaine-Exposed Children.” Pediatrics. 118:2014-2024.

White, A. and Swartzwelder, H, 2004. "Hippocampal Function during Adolescence: A Unique Target of Ethanol Effects." Annals of the New York Academy of Sciences. 1021(Adolescent Brain Development: Vulnerabilities and Opportunities): 206-220.

Zhang, L., Thomas, K., Davidson, M., Casey, B., Heier, L., Ulug, A. 2005. "MR Quantitation of Volume and Diffusion Changes in the Developing Brain." American Journal of Neuroradiology. 26:45-49. 
Table 1: Proportion of Days Drank Past Month

\begin{tabular}{|c|c|c|c|c|c|}
\hline Males & $(1)$ & $(2)$ & $(3)$ & $\begin{array}{c}\text { Low-Migration } \\
\text { (4) }\end{array}$ & $\begin{array}{c}\text { Low Education } \\
\text { (5) }\end{array}$ \\
\hline Sometimes Legal Age, Ages 18 to 20 & $\begin{array}{l}-0.002 \\
(0.006)\end{array}$ & $\begin{array}{l}-0.004 \\
(0.006)\end{array}$ & $\begin{array}{l}-0.004 \\
(0.006)\end{array}$ & $\begin{array}{l}-0.006 \\
(0.007)\end{array}$ & $\begin{array}{c}0.010 \\
(0.011)\end{array}$ \\
\hline Always Legal Age, Ages 18 to 20 & $\begin{array}{c}0.004 \\
(0.009)\end{array}$ & $\begin{array}{c}0.002 \\
(0.009)\end{array}$ & $\begin{array}{c}0.002 \\
(0.009)\end{array}$ & $\begin{array}{c}0.002 \\
(0.012)\end{array}$ & $\begin{array}{c}0.017 \\
(0.018)\end{array}$ \\
\hline Proportion of Time Legal Age, Ages 18 to 20 & $\begin{array}{c}0.002 \\
(0.009) \\
\end{array}$ & $\begin{array}{c}0.001 \\
(0.009)\end{array}$ & $\begin{array}{c}0.001 \\
(0.009)\end{array}$ & $\begin{array}{l}-0.009 \\
(0.012)\end{array}$ & $\begin{array}{c}0.013 \\
(0.019) \\
\end{array}$ \\
\hline Quadratic State-Year of Birth Time Trend & No & Yes & Yes & Yes & Yes \\
\hline Average Beer Tax (18 to current year) & No & Yes & Yes & Yes & Yes \\
\hline Education & No & No & Yes & Yes & Yes \\
\hline Number of Observations & 170777 & 170777 & 170777 & 94820 & 61439 \\
\hline Mean of Dependent Variable & 0.19 & 0.19 & 0.19 & 0.17 & 0.17 \\
\hline Females & (1) & (2) & (3) & $\begin{array}{c}\text { Low-Migration } \\
\text { (4) }\end{array}$ & $\begin{array}{c}\text { Low Education } \\
\text { (5) }\end{array}$ \\
\hline Sometimes Legal Age, Ages 18 to 20 & $\begin{array}{c}0.003 \\
(0.004)\end{array}$ & $\begin{array}{c}0.004 \\
(0.004)\end{array}$ & $\begin{array}{c}0.003 \\
(0.004)\end{array}$ & $\begin{array}{c}0.005 \\
(0.005)\end{array}$ & $\begin{array}{c}0.000 \\
(0.007)\end{array}$ \\
\hline Always Legal Age, Ages 18 to 20 & $\begin{array}{c}0.004 \\
(0.006)\end{array}$ & $\begin{array}{c}0.004 \\
(0.006)\end{array}$ & $\begin{array}{c}0.004 \\
(0.006)\end{array}$ & $\begin{array}{c}0.013 \\
(0.008)\end{array}$ & $\begin{array}{l}-0.001 \\
(0.010)\end{array}$ \\
\hline Proportion of Time Legal Age, Ages 18 to 20 & $\begin{array}{l}-0.001 \\
(0.006)\end{array}$ & $\begin{array}{l}-0.001 \\
(0.006)\end{array}$ & $\begin{array}{l}-0.001 \\
(0.006)\end{array}$ & $\begin{array}{c}0.006 \\
(0.008)\end{array}$ & $\begin{array}{l}-0.004 \\
(0.010)\end{array}$ \\
\hline Quadratic State-Year of Birth Time Trend & No & Yes & Yes & Yes & Yes \\
\hline Average Beer Tax (18 to current year) & No & Yes & Yes & Yes & Yes \\
\hline Education & No & No & Yes & Yes & Yes \\
\hline Number of Observations & 248868 & 248868 & 248868 & 138468 & 81334 \\
\hline Mean of Dependent Variable & 0.10 & 0.10 & 0.10 & 0.09 & 0.07 \\
\hline
\end{tabular}

Notes:

1. All models include state-year, year of birth, and race fixed effects; weighted by BRFSS final weights

2. Robust (clustered on state-year) standard errors in parentheses. 
Table 2: Number of Drinks in Past Month

\begin{tabular}{|c|c|c|c|c|c|}
\hline Males & $(1)$ & $(2)$ & $(3)$ & $\begin{array}{l}\text { Low-Migration } \\
\text { (4) }\end{array}$ & $\begin{array}{c}\text { Low Education } \\
\text { (5) }\end{array}$ \\
\hline $\begin{array}{l}\text { Sometimes Legal Age, Ages } 18 \text { to } 20 \\
\text { Always Legal Age, Ages } 18 \text { to } 20\end{array}$ & $\begin{array}{l}1.70 \\
(1.16) \\
3.19^{*} \\
(1.71)\end{array}$ & $\begin{array}{c}1.61 \\
(1.15) \\
3.21^{*} \\
(1.70)\end{array}$ & $\begin{array}{c}1.71 \\
(1.15) \\
3.41 * * \\
(1.71)\end{array}$ & $\begin{array}{c}1.63 \\
(1.39) \\
3.71 \\
(2.25)\end{array}$ & $\begin{array}{c}3.76 \\
(2.48) \\
5.88 \\
(3.69)\end{array}$ \\
\hline Proportion of Time Legal Age, Ages 18 to 20 & $\begin{array}{l}3.43 * * \\
(1.71) \\
\end{array}$ & $\begin{array}{l}3.38^{* * *} \\
(1.71) \\
\end{array}$ & $\begin{array}{l}3.53 * * \\
(1.71) \\
\end{array}$ & $\begin{array}{c}3.22 \\
(2.27) \\
\end{array}$ & $\begin{array}{l}7.68^{*} \\
(4.12) \\
\end{array}$ \\
\hline $\begin{array}{l}\text { Quadratic State-Year of Birth Time Trend } \\
\text { Average Beer Tax ( } 18 \text { to current year) } \\
\text { Education }\end{array}$ & $\begin{array}{l}\text { No } \\
\text { No } \\
\text { No }\end{array}$ & $\begin{array}{l}\text { Yes } \\
\text { Yes } \\
\text { No }\end{array}$ & $\begin{array}{l}\text { Yes } \\
\text { Yes } \\
\text { Yes }\end{array}$ & $\begin{array}{l}\text { Yes } \\
\text { Yes } \\
\text { Yes }\end{array}$ & $\begin{array}{l}\text { Yes } \\
\text { Yes } \\
\text { Yes }\end{array}$ \\
\hline $\begin{array}{l}\text { Number of Observations } \\
\text { Mean of Dependent Variable }\end{array}$ & $\begin{array}{r}169411 \\
19.16\end{array}$ & $\begin{array}{r}169411 \\
19.16 \\
\end{array}$ & $\begin{array}{r}169411 \\
19.16 \\
\end{array}$ & $\begin{array}{c}94075 \\
18.49\end{array}$ & $\begin{array}{r}60710 \\
21.23\end{array}$ \\
\hline Females & $(1)$ & $(2)$ & $(3)$ & $\begin{array}{c}\text { Low-Migration } \\
(4)\end{array}$ & $\begin{array}{c}\text { Low Education } \\
(5)\end{array}$ \\
\hline $\begin{array}{l}\text { Sometimes Legal Age, Ages } 18 \text { to } 20 \\
\text { Always Legal Age, Ages } 18 \text { to } 20\end{array}$ & $\begin{array}{c}-0.09 \\
(0.41) \\
0.18 \\
(0.60)\end{array}$ & $\begin{array}{c}-0.03 \\
(0.42) \\
0.19 \\
(0.60)\end{array}$ & $\begin{array}{c}-0.04 \\
(0.42) \\
0.19 \\
(0.60)\end{array}$ & $\begin{array}{c}0.02 \\
(0.56) \\
0.66 \\
(0.77) \\
\end{array}$ & $\begin{array}{l}-0.72 \\
(0.96) \\
-1.24 \\
(1.17) \\
\end{array}$ \\
\hline Proportion of Time Legal Age, Ages 18 to 20 & $\begin{array}{l}-0.53 \\
(0.58)\end{array}$ & $\begin{array}{l}-0.54 \\
(0.59)\end{array}$ & $\begin{array}{l}-0.55 \\
(0.59)\end{array}$ & $\begin{array}{l}-0.10 \\
(0.77)\end{array}$ & $\begin{array}{l}-2.34 \\
(1.42)\end{array}$ \\
\hline $\begin{array}{l}\text { Quadratic State-Year of Birth Time Trend } \\
\text { Average Beer Tax (18 to current year) } \\
\text { Education }\end{array}$ & $\begin{array}{l}\text { No } \\
\text { No } \\
\text { No }\end{array}$ & $\begin{array}{l}\text { Yes } \\
\text { Yes } \\
\text { No }\end{array}$ & $\begin{array}{l}\text { Yes } \\
\text { Yes } \\
\text { Yes }\end{array}$ & $\begin{array}{l}\text { Yes } \\
\text { Yes } \\
\text { Yes }\end{array}$ & $\begin{array}{l}\text { Yes } \\
\text { Yes } \\
\text { Yes }\end{array}$ \\
\hline $\begin{array}{l}\text { Number of Observations } \\
\text { Mean of Dependent Variable }\end{array}$ & $\begin{array}{r}247593 \\
6.79 \\
\end{array}$ & $\begin{array}{c}247593 \\
6.79 \\
\end{array}$ & $\begin{array}{c}247593 \\
6.79 \\
\end{array}$ & $\begin{array}{r}137793 \\
6.20 \\
\end{array}$ & $\begin{array}{r}80705 \\
5.84 \\
\end{array}$ \\
\hline
\end{tabular}

Notes:

1. All models include state-year, year of birth, and race fixed effects; weighted by BRFSS final weights

2. Robust (clustered on state-year) standard errors in parentheses. 
Table 3: Had 5 or More Drinks at One Time in Past Month

\begin{tabular}{|c|c|c|c|c|c|}
\hline Males & (1) & (2) & (3) & $\begin{array}{l}\text { Low-Migration } \\
\text { (4) }\end{array}$ & $\begin{array}{l}\text { Low Education } \\
\text { (5) }\end{array}$ \\
\hline Sometimes Legal Age, Ages 18 to 20 & $\begin{array}{c}0.02 \\
(0.01)\end{array}$ & $\begin{array}{c}0.01 \\
(0.01)\end{array}$ & $\begin{array}{c}0.01 \\
(0.01)\end{array}$ & $\begin{array}{c}0.01 \\
(0.01)\end{array}$ & $\begin{array}{l}0.04 * * \\
(0.020)\end{array}$ \\
\hline Always Legal Age, Ages 18 to 20 & $\begin{array}{c}0.02 \\
(0.02)\end{array}$ & $\begin{array}{c}0.02 \\
(0.02)\end{array}$ & $\begin{array}{c}0.02 \\
(0.02)\end{array}$ & $\begin{array}{c}0.03 \\
(0.02)\end{array}$ & $\begin{array}{l}0.06^{* *} \\
(0.03)\end{array}$ \\
\hline Proportion of Time Legal Age, Ages 18 to 20 & $\begin{array}{c}0.02 \\
(0.02)\end{array}$ & $\begin{array}{c}0.02 \\
(0.02)\end{array}$ & $\begin{array}{c}0.02 \\
(0.02)\end{array}$ & $\begin{array}{c}0.02 \\
(0.02)\end{array}$ & $\begin{array}{c}0.05 \\
(0.03)\end{array}$ \\
\hline $\begin{array}{l}\text { Quadratic State-Year of Birth Time Trend } \\
\text { Average Beer Tax (18 to current year) } \\
\text { Education }\end{array}$ & $\begin{array}{l}\text { No } \\
\text { No } \\
\text { No }\end{array}$ & $\begin{array}{l}\text { Yes } \\
\text { Yes } \\
\text { No }\end{array}$ & $\begin{array}{l}\text { Yes } \\
\text { Yes } \\
\text { Yes }\end{array}$ & $\begin{array}{l}\text { Yes } \\
\text { Yes } \\
\text { Yes }\end{array}$ & $\begin{array}{l}\text { Yes } \\
\text { Yes } \\
\text { Yes }\end{array}$ \\
\hline $\begin{array}{l}\text { Number of Observations } \\
\text { Mean of Dependent Variable }\end{array}$ & $\begin{array}{c}170448 \\
0.30\end{array}$ & $\begin{array}{c}170448 \\
0.30\end{array}$ & $\begin{array}{c}170448 \\
0.30\end{array}$ & $\begin{array}{r}94474 \\
0.31\end{array}$ & $\begin{array}{r}61130 \\
0.31\end{array}$ \\
\hline Females & $(1)$ & $(2)$ & $(3)$ & $\begin{array}{c}\text { Low-Migration } \\
(4)\end{array}$ & $\begin{array}{c}\text { Low Education } \\
(5)\end{array}$ \\
\hline $\begin{array}{l}\text { Sometimes Legal Age, Ages } 18 \text { to } 20 \\
\text { Always Legal Age, Ages } 18 \text { to } 20\end{array}$ & $\begin{array}{c}0.000 \\
(0.008) \\
0.001 \\
(0.011)\end{array}$ & $\begin{array}{c}0.001 \\
(0.008) \\
0.003 \\
(0.011)\end{array}$ & $\begin{array}{c}0.001 \\
(0.008) \\
0.004 \\
(0.011)\end{array}$ & $\begin{array}{c}0.008 \\
(0.010) \\
0.010 \\
(0.014)\end{array}$ & $\begin{array}{l}-0.013 \\
(0.014) \\
-0.019 \\
(0.020)\end{array}$ \\
\hline Proportion of Time Legal Age, Ages 18 to 20 & $\begin{array}{l}-0.008 \\
(0.011) \\
\end{array}$ & $\begin{array}{l}-0.006 \\
(0.011) \\
\end{array}$ & $\begin{array}{l}-0.006 \\
(0.011)\end{array}$ & $\begin{array}{c}0.003 \\
(0.014)\end{array}$ & $\begin{array}{l}-0.032 \\
(0.021)\end{array}$ \\
\hline $\begin{array}{l}\text { Quadratic State-Year of Birth Time Trend } \\
\text { Average Beer Tax ( } 18 \text { to current year) } \\
\text { Education }\end{array}$ & $\begin{array}{l}\text { No } \\
\text { No } \\
\text { No }\end{array}$ & $\begin{array}{l}\text { Yes } \\
\text { Yes } \\
\text { No }\end{array}$ & $\begin{array}{l}\text { Yes } \\
\text { Yes } \\
\text { Yes }\end{array}$ & $\begin{array}{l}\text { Yes } \\
\text { Yes } \\
\text { Yes }\end{array}$ & $\begin{array}{l}\text { Yes } \\
\text { Yes } \\
\text { Yes }\end{array}$ \\
\hline $\begin{array}{l}\text { Number of Observations } \\
\text { Mean of Dependent Variable }\end{array}$ & $\begin{array}{c}248848 \\
0.11\end{array}$ & $\begin{array}{c}248625 \\
0.11\end{array}$ & $\begin{array}{c}248625 \\
0.11\end{array}$ & $\begin{array}{c}138281 \\
0.11\end{array}$ & $\begin{array}{r}81181 \\
0.11\end{array}$ \\
\hline
\end{tabular}

Notes:

1. All models include state-year, year of birth, and race fixed effects; weighted by BRFSS final weights

2. Robust (clustered on state-year) standard errors in parentheses. 
Table 4: Proportion of Days had 5 or More Drinks at One Time in Past Month

\begin{tabular}{|c|c|c|c|c|c|}
\hline Males & $(1)$ & $(2)$ & $(3)$ & $\begin{array}{c}\text { Low-Migration } \\
\text { (4) }\end{array}$ & $\begin{array}{c}\text { Low Education } \\
\text { (5) }\end{array}$ \\
\hline Sometimes Legal Age, Ages 18 to 20 & $\begin{array}{l}0.004^{*} \\
(0.003)\end{array}$ & $\begin{array}{l}0.004^{*} \\
(0.002)\end{array}$ & $\begin{array}{l}0.005^{*} \\
(0.002)\end{array}$ & $\begin{array}{c}0.006^{* *} \\
(0.003)\end{array}$ & $\begin{array}{c}0.010^{*} \\
(0.006)\end{array}$ \\
\hline Always Legal Age, Ages 18 to 20 & $\begin{array}{l}0.015 * * \\
(0.005)\end{array}$ & $\begin{array}{l}0.015 * * \\
(0.005)\end{array}$ & $\begin{array}{c}0.016 * * \\
(0.005)\end{array}$ & $\begin{array}{c}0.014 * * \\
(0.006)\end{array}$ & $\begin{array}{c}0.027 * * \\
(0.010)\end{array}$ \\
\hline Proportion of Time Legal Age, Ages 18 to 20 & $\begin{array}{l}0.012^{* *} \\
(0.005)\end{array}$ & $\begin{array}{l}0.012^{* *} \\
(0.005)\end{array}$ & $\begin{array}{l}0.012^{* *} \\
(0.005)\end{array}$ & $\begin{array}{l}0.012^{*} \\
(0.006)\end{array}$ & $\begin{array}{c}0.026^{* * *} \\
(0.011)\end{array}$ \\
\hline Quadratic State-Year of Birth Time Trend & No & Yes & Yes & Yes & Yes \\
\hline Average Beer Tax (18 to current year) & No & Yes & Yes & Yes & Yes \\
\hline Education & No & No & Yes & Yes & Yes \\
\hline Number of Observations & 118805 & 118805 & 118805 & 66620 & 42974 \\
\hline Mean of Dependent Variable & 0.04 & 0.04 & 0.04 & 0.04 & 0.05 \\
\hline Females & (1) & (2) & (3) & $\begin{array}{c}\text { Low-Migration } \\
\text { (4) }\end{array}$ & $\begin{array}{c}\text { Low Education } \\
\text { (5) }\end{array}$ \\
\hline Sometimes Legal Age, Ages 18 to 20 & $\begin{array}{c}0.001 \\
(0.001)\end{array}$ & $\begin{array}{c}0.001 \\
(0.001)\end{array}$ & $\begin{array}{c}0.001 \\
(0.001)\end{array}$ & $\begin{array}{c}0.002 \\
(0.002)\end{array}$ & $\begin{array}{c}-0.001 \\
(0.004)\end{array}$ \\
\hline Always Legal Age, Ages 18 to 20 & $\begin{array}{c}0.001 \\
(0.002)\end{array}$ & $\begin{array}{c}0.001 \\
(0.002)\end{array}$ & $\begin{array}{c}0.001 \\
(0.002)\end{array}$ & $\begin{array}{c}0.003 \\
(0.003)\end{array}$ & $\begin{array}{c}0.001 \\
(0.004)\end{array}$ \\
\hline Proportion of Time Legal Age, Ages 18 to 20 & $\begin{array}{c}0.000 \\
(0.002) \\
\end{array}$ & $\begin{array}{c}0.000 \\
(0.002)\end{array}$ & $\begin{array}{c}0.000 \\
(0.002)\end{array}$ & $\begin{array}{c}0.003 \\
(0.002) \\
\end{array}$ & $\begin{array}{l}-0.001 \\
(0.005)\end{array}$ \\
\hline Quadratic State-Year of Birth Time Trend & No & Yes & Yes & Yes & Yes \\
\hline Average Beer Tax (18 to current year) & No & Yes & Yes & Yes & Yes \\
\hline Education & No & No & Yes & Yes & Yes \\
\hline Number of Observations & 170604 & 170463 & 170463 & 95731 & 56992 \\
\hline Mean of Dependent Variable & 0.01 & 0.01 & 0.01 & 0.01 & 0.01 \\
\hline
\end{tabular}

Notes:

1. All models include state-year, year of birth, and race fixed effects; weighted by BRFSS final weights

2. Robust (clustered on state-year) standard errors in parentheses. 
Table 5: Mental Health, Physical Health, and Smoking

\begin{tabular}{|c|c|c|c|c|c|c|}
\hline & \multicolumn{2}{|c|}{$\begin{array}{c}\text { Proportion of Days Past } \\
\text { Month in Poor Mental Health }\end{array}$} & \multicolumn{2}{|c|}{$\begin{array}{c}\text { Proportion of Days in Past } \\
\text { Month in Poor Physical } \\
\text { Health }\end{array}$} & \multicolumn{2}{|c|}{ Smoked in the Past Month } \\
\hline & Males & Females & Males & Females & Males & Females \\
\hline Sometimes Legal Age, Ages 18 to 20 & $\begin{array}{l}-0.008 \\
(0.013)\end{array}$ & $\begin{array}{l}-0.013 \\
(0.008)\end{array}$ & $\begin{array}{c}0.007 \\
(0.010)\end{array}$ & $\begin{array}{l}-0.009 \\
(0.008)\end{array}$ & $\begin{array}{l}-0.004 \\
(0.023)\end{array}$ & $\begin{array}{l}-0.023 \\
(0.014)\end{array}$ \\
\hline Always Legal Age, Ages 18 to 20 & $\begin{array}{c}0.011 \\
(0.019) \\
\end{array}$ & $\begin{array}{l}-0.006 \\
(0.013)\end{array}$ & $\begin{array}{c}0.015 \\
(0.014)\end{array}$ & $\begin{array}{l}-0.003 \\
(0.011)\end{array}$ & $\begin{array}{l}-0.025 \\
(0.037)\end{array}$ & $\begin{array}{l}-0.008 \\
(0.024)\end{array}$ \\
\hline Proportion of Time Legal Age, Ages 18 to 20 & $\begin{array}{l}-0.001 \\
(0.016)\end{array}$ & $\begin{array}{l}-0.010 \\
(0.013)\end{array}$ & $\begin{array}{c}0.006 \\
(0.013)\end{array}$ & $\begin{array}{c}-0.023 * * \\
(0.010) \\
\end{array}$ & $\begin{array}{l}-0.015 \\
(0.031)\end{array}$ & $\begin{array}{l}-0.022 \\
(0.021)\end{array}$ \\
\hline State-Year of Birth (Quadratic) Trend & Yes & Yes & Yes & Yes & Yes & Yes \\
\hline State Average Beer Tax- Age 18 to Current Year & Yes & Yes & Yes & Yes & Yes & Yes \\
\hline Education & Yes & Yes & Yes & Yes & Yes & Yes \\
\hline Number of Observations & 103599 & 155250 & 103899 & 155242 & 128921 & 192070 \\
\hline Mean of Dependent Variable & 0.10 & 0.10 & 0.08 & 0.10 & 0.28 & 0.25 \\
\hline
\end{tabular}

Notes:

1. All models include state-year, year of birth, and race fixed effects; weighted by BRFSS final weights

2. Robust (clustered on state-year) standard errors in parentheses. 
Table 6: Fatal Traffic Accidents per 100,000

\begin{tabular}{|c|c|c|c|c|c|c|}
\hline \multirow[b]{2}{*}{ All Fatalities } & \multicolumn{3}{|c|}{ Males } & \multicolumn{3}{|c|}{ Females } \\
\hline & & & $\begin{array}{c}\text { Low } \\
\text { Migration } \\
\end{array}$ & & & $\begin{array}{c}\text { Low } \\
\text { Migration } \\
\end{array}$ \\
\hline & (1) & (2) & $(3)$ & $(1)$ & $(2)$ & (3) \\
\hline $\begin{array}{l}\text { Sometimes Legal Age, Ages } 18 \text { to } 20 \\
\text { Always Legal Age, Ages } 18 \text { to } 20\end{array}$ & $\begin{array}{l}-0.98 \\
(0.61) \\
-1.29 * \\
(0.70) \\
\end{array}$ & $\begin{array}{c}0.93 \\
(0.80) \\
3.06^{* *} \\
(1.13) \\
\end{array}$ & $\begin{array}{l}1.37 \\
(1.06) \\
3.50 * * \\
(1.48)\end{array}$ & $\begin{array}{l}0.17 \\
(0.27) \\
-0.02 \\
(0.32) \\
\end{array}$ & $\begin{array}{c}0.33 \\
(0.44) \\
0.11 \\
(0.72) \\
\end{array}$ & $\begin{array}{c}0.27 \\
(0.58) \\
-0.05 \\
(0.92) \\
\end{array}$ \\
\hline Proportion of Time Legal Age, Ages 18 to 20 & $\begin{array}{c}-1.49^{* *} \\
(0.69)\end{array}$ & $\begin{array}{l}2.55^{* *} \\
(1.20)\end{array}$ & $\begin{array}{l}3.04 * \\
(1.61)\end{array}$ & $\begin{array}{l}-0.11 \\
(0.32)\end{array}$ & $\begin{array}{l}-0.20 \\
(0.72)\end{array}$ & $\begin{array}{l}-0.70 \\
(0.93)\end{array}$ \\
\hline $\begin{array}{l}\text { Quadratic State-Year of Birth Time Trend } \\
\text { Average Beer Tax ( } 18 \text { to current year) }\end{array}$ & $\begin{array}{l}\text { No } \\
\text { No }\end{array}$ & $\begin{array}{l}\text { Yes } \\
\text { Yes }\end{array}$ & $\begin{array}{l}\text { Yes } \\
\text { Yes }\end{array}$ & $\begin{array}{l}\text { No } \\
\text { No }\end{array}$ & $\begin{array}{l}\text { Yes } \\
\text { Yes }\end{array}$ & $\begin{array}{l}\text { Yes } \\
\text { Yes }\end{array}$ \\
\hline $\begin{array}{l}\text { Number of Observations } \\
\text { Mean of Dependent Variable }\end{array}$ & $\begin{array}{r}8988 \\
27.71 \\
\end{array}$ & $\begin{array}{l}8988 \\
27.71\end{array}$ & $\begin{array}{r}5357 \\
29.83 \\
\end{array}$ & $\begin{array}{l}8988 \\
9.51\end{array}$ & $\begin{array}{l}8988 \\
9.51 \\
\end{array}$ & $\begin{array}{l}5357 \\
10.25 \\
\end{array}$ \\
\hline & \multicolumn{3}{|c|}{ Males } & \multicolumn{3}{|c|}{ Females } \\
\hline Fatalities Between 8pm and 12am & & & $\begin{array}{c}\text { Low } \\
\text { Migration }\end{array}$ & & & $\begin{array}{c}\text { Low } \\
\text { Migration }\end{array}$ \\
\hline & $(1)$ & $(2)$ & $(3)$ & $(1)$ & $(2)$ & $(3)$ \\
\hline $\begin{array}{l}\text { Sometimes Legal Age, Ages } 18 \text { to } 20 \\
\text { Always Legal Age, Ages } 18 \text { to } 20\end{array}$ & $\begin{array}{l}-0.44^{*} \\
(0.24) \\
-0.34 \\
(0.26) \\
\end{array}$ & $\begin{array}{c}0.21 \\
(0.36) \\
0.78 \\
(0.56) \\
\end{array}$ & $\begin{array}{c}0.49 \\
(0.46) \\
0.94 \\
(0.73) \\
\end{array}$ & $\begin{array}{c}0.08 \\
(0.11) \\
0.23^{*} \\
(0.128) \\
\end{array}$ & $\begin{array}{c}0.20 \\
(0.17) \\
0.41 \\
(0.28) \\
\end{array}$ & $\begin{array}{c}0.27 \\
(0.23) \\
0.47 \\
(0.37) \\
\end{array}$ \\
\hline Proportion of Time Legal Age, Ages 18 to 20 & $\begin{array}{l}-0.38 \\
(0.26)\end{array}$ & $\begin{array}{c}0.90 \\
(0.58) \\
\end{array}$ & $\begin{array}{l}1.52 * * \\
(0.77) \\
\end{array}$ & $\begin{array}{l}0.24 * \\
(0.13) \\
\end{array}$ & $\begin{array}{l}0.59 * * \\
(0.28)\end{array}$ & $\begin{array}{c}0.54 \\
(0.37)\end{array}$ \\
\hline $\begin{array}{l}\text { Quadratic State-Year of Birth Time Trend } \\
\text { Average Beer Tax ( } 18 \text { to current year) }\end{array}$ & $\begin{array}{l}\text { No } \\
\text { No }\end{array}$ & $\begin{array}{l}\text { Yes } \\
\text { Yes }\end{array}$ & $\begin{array}{l}\text { Yes } \\
\text { Yes }\end{array}$ & $\begin{array}{l}\text { No } \\
\text { No }\end{array}$ & $\begin{array}{l}\text { Yes } \\
\text { Yes }\end{array}$ & $\begin{array}{l}\text { Yes } \\
\text { Yes }\end{array}$ \\
\hline $\begin{array}{l}\text { Number of Observations } \\
\text { Mean of Dependent Variable }\end{array}$ & $\begin{array}{l}8988 \\
7.18\end{array}$ & $\begin{array}{l}8988 \\
7.18 \\
\end{array}$ & $\begin{array}{r}5357 \\
7.59 \\
\end{array}$ & $\begin{array}{l}8988 \\
1.80 \\
\end{array}$ & $\begin{array}{l}8988 \\
1.80 \\
\end{array}$ & $\begin{array}{r}5357 \\
1.83 \\
\end{array}$ \\
\hline
\end{tabular}

\section{Notes:}

1. The unit of observation is the number of traffic fatalities per 100,000 persons in the cell, which is defined by state, year and year of birth.

2. All models include state-year and year of birth fixed effects.

3. Robust (clustered on state-year) standard errors in parentheses. 